\title{
WHITMAN'S SIGN OF PARTING: "SO LONG!" AS L'ENVOI
}

Kenneth M. Price

Cynthia G. Bernstein

"So LONG!" FIRST APPEARED as the final poem of Leaves of Grass in 1860, and Whitman - though he changed the positioning of much else-kept it always as a sign of parting. The function of this closing statement can be clarified by noting the indebtedness of "So long!" to l'envoi, the envoy or send-off. Since the time of Ovid, authors have been bidding good-bye to their books, closing literary works with a curious speech act. ${ }^{1}$ The act of termination is sometimes part of a literary work, at other times an entire work. Whitman mulled over the form and function of l'envoi in the late 1850 s, eventually transforming conventional practice in powerful ways. Most closing poems call attention to the literary quality of a text by explicitly referring to the fictive nature of the production. In contrast, Whitman stresses the personality of the author and denies his literariness: "Camerado, this is no book, / Who touches this touches a man."2 Moreover, his sign of parting is expressed in the vernacular and emphasizes reunification rather than separation. Whitman's poem is a highly self-conscious speech act that addresses both readers of the future and writers of the past.

The evidence of Whitman's interest in l'envoi comes from his notebooks. He scrawled the following words, probably in 1857, in one of his entries:

\section{Poem L'Envoy}

-From one state to another - from the East to the West - from Massachusetts to Texas $\& c^{3}$

This spare passage offers few clues to Whitman's thinking about l'envoi. There is no indication of where he might have encountered the idea of l'envoi nor of how full a sense of this particular literary tradition he possessed. The notebook passage explains neither his later transformation of l'envoi to "So long!" nor the implications of this vernacular substitution.

Whitman's notebook passage does, however, suggest the association between "So long!" and the tradition of l'envoi. The passage treats l'envoi largely in spatial terms, as a message sent from one region to another. Poets since Roman times have bid good-bye as they sent their 
books to distant places. Ovid, after being banished to a frontier town, sent by courier poems to Rome, addressing his fortunate "little book" with envy. Petrarch, in "Italia mia" and in other canzoni, closed with a direct address to his song, urging it to "go" in a way that underscores the poignancy of the poet's own exile. ${ }^{4}$ Chaucer, in the famous conclusion to Troilus, made a notable early use of l'envoi by transforming the theme of exile from spatial to temporal terms. That is, Chaucer seeks connection not with another place but with another time.

Go, litel bok, go, litel myn tragedye,

Ther God thi makere yet, er that he dye,

So sende myght to make in som comedye!

But litel book, no makyng thow n'envie

But subgit be to alle poesye;

And kis the steppes, where as thow sees pace

Virgile, Ovide, Omer, Lucan, and Stace. ${ }^{5}$

The address to the book cuts across geographical boundaries and across time periods. Author after author turns to the stock phrase "go, little book" (regardless of the size of the tome). To invoke this phrase is, as Chaucer noted, to kiss the steps of the past. The moment of releasing a work, the instant of letting go, moves authors to expressions of modesty (often only the pose of modesty) and to a sense of community with others who have experienced that precarious edge where the next step is a launch into public scrutiny.

Authors are aided in their achievement of closure by turning to what has already been textualized and historicized, by working with the expectations readers bring to poems entitled l'envoi or containing the "go, little book" conceit. Of course some writers, Edmund Spenser for one, have used l'envoi at the outset of a book, ${ }^{6}$ but it is much more common as a concluding device. The moment of parting is especially telling because of the association of mortality with closing. Frequently poets demonstrate their ingenuity by playing new variations on an established theme. Thus Robert Southey, for example, imagines in "Little Book, in Green and Gold" the worms that will overcome his book (rather than, as one might have expected, the human body), unless his book has the good fortune to find "some collector" who will "as a prize, re-bind thee."7

So many poems of parting have been written that one can only conjecture about where Whitman first encountered l'envoi. Possibly it was in Chaucer, Spenser, Sir Walter Scott, or James Russell Lowell-all poets he was familiar with. The most likely source, however, is Henry Wadsworth Longfellow, whose "L'Envoi" concludes and summarizes Voices of the Night. In the following three stanzas, Longfellow treats the meeting of past, present, and future: 
Ye voices, that arose

After the Evening's close,

And whispered to my restless heart repose!

Go, breathe it in the ear

Of all who doubt and fear,

And say to them, "Be of good cheer!"

Tongues of the dead, not lost,

But speaking from death's frost,

Like fiery tongues at Pentecost $!^{8}$

The notion that the past is dead yet that it might be revitalized reminds one of the 1855 Preface to Leaves of Grass ("He drags the dead out of their coffins and stands them again on their feet . . . he says to the past, Rise and walk before me that I may realize you"). ${ }^{9}$ Moreover, the emphasis on the audience and the intimacy of "breathe it in the ear" is also reminiscent of Whitman.

Longfellow actually wrote several poems entitled "L'Envoi." A second poem, subtitled "The Poet and His Songs," argues,

His, and not his, are the lays

He sings; and their fame

Is his, and not his; and the praise

And the pride of a name.

For voices pursue him by day,

And haunt him by night,

And he listens, and needs must obey,

When the Angel says, "Write!"10

This poem is especially interesting in its claim that a poem is " $\mathrm{His}$, and not his." Longfellow, widely learned in Western literary culture, acknowledges that a poem is both a personal expression and a haunted monument, a linguistic artifice of the present that perpetuates texts of the past and is constructed out of them.

Like Longfellow, Whitman exploits the powerful intertextual potential of l'envoi. Authors employing l'envoi inevitably engage with earlier versions by other authors. Through its position as the closing poem of Leaves of Grass, "So long!" invokes the rich tradition of l'envoi. Operating beyond its limited denotative meaning, "So long!" is a sign that produces expectations in readers because of its retrospective association with other poems in the genre.

At the same time, Whitman's poem departs from the very tradition it invokes. Instead of producing his own projected "L'Envoy," Whitman developed his brilliant vernacular transformation of the tradition. 
He could have opted for any number of titles to convey the sense of an ending. His selection of "So long!" treats completion as a moment of departure, as a speech event, a colloquial interaction between the poet and his audience. As he explained to William Sloane Kennedy, the expression "So long!" was "A salutation of departure, greatly used among sailors, sports, and prostitutes. The sense of it is 'Till we meet again,'-conveying an inference that somehow they will doubtless so meet, sooner or later." 11 By turning to the expression "So long!" Whitman probably means to have things both ways: to benefit from the rich associations of l'envoi and to reconfirm his originality.

Besides calling to mind intertextual associations with other poems in the tradition of l'envoi, "So long!" rehearses Whitman's own key themes and images through intratextual associations with other poems in Leaves of Grass. Whitman lists in "So long!" the subjects of previous poems: "As I have announced myself on immortality, the body, procreation, hauteur, prudence ... . - I adhere to all" (section 8). Toward the end of the poem, Whitman points again to his own previous work: "Enough, O summed-up past!" (section 22). But the clearest example of intratextuality is the repetition of language and ideas from the poem (Number 24) that closes the "Leaves of Grass" section in the 1860 edition of Leaves:

Lift me close to your face till I whisper,

What you are holding is in reality no book, nor part of a book,

It is a man, flushed and full-blooded-it is I-So long!

We must separate-Here! take from my lips this kiss,

Whoever you are, I give it especially to you;

So long-and I hope we shall meet again.

Within the 1860 Leaves of Grass, then, the poem that closes the whole echoes the one that closes the section with the same title.

The later poem elaborates on key ideas of the earlier one. Like Number 24, "So long!" emphasizes the text's representation of speech through verba dicendi, performative verbs signifying orality. "I whisper," in the first line of Number 24, above, is repeated in section 6 of "So long!": "While my pleasure is yet at the full, I whisper So long." Other first-person, present-tense verbs in "So long!" are used to express the oral nature of the poem: "I announce" (used repeatedly in sections $1,10,11,12,13,14)$; "I proclaim" (section 7); "I demand" (section 9); "I say" (section 12). Whitman's strategy is to use performative prefixes that, by naming the illocutionary act ${ }^{12}$ they perform, emphasize the poem's representation of speech.

In ordinary conversation, however, one rarely expresses intent with a performative prefix. ${ }^{13}$ To preface a remark with "I whisper," "I announce," "I proclaim," "I demand," or "I say" is to call special 
attention to the force with which a statement is made. Frequently, Whitman's announcements concern not what is true now but what will be true, perhaps by virtue of his speech act. "I announce that the identity of These States is a single identity only" (section 11): the announcement may be considered a representative, albeit a hopeful one in view of the impending Civil War; or it may be read as a declaration, an attempt by the speaker to make the nation cohere by declaring it to be unified. Much of "So long!" supports the second interpretation; the persona is not simply asserting his beliefs, but predicting, and striving to create, the future. Whitman's language, then, is no simple imitation of speech; rather, it underscores the power of speech.

Whitman's style is characterized by his representation of illocutionary force directed toward the reader. C. Carroll Hollis notes that Whitman exceeds all other American and English poets in number of illocutionary acts, thereby creating "the stylistic feature of Leaves up to and including the 1860 edition." 14 Through this "great device," Hollis argues, Whitman was able to discover his prophetic voice. Of course, it is not as though other poets avoid illocutionary force altogether. The command associated with the typical l'envoi, "go, little book," represents a directive, an illocutionary act addressed to the text. But Whitman's commands - "take this kiss"; "Do not forget me"; "Remember my words" - are not addressed to his Leaves (section 23). The difference, then, is in the addressee; whereas the poetic imperatives of the traditional l'envoi are addressed to an inanimate text, Whitman's are addressed to his reader. In neither case, as John Hollander points out, do the commands indicate genuine conversation, since neither a book nor an unseen reader is capable of actual response to the commands. ${ }^{15}$ But Whitman's address to the reader is more in keeping with the sense of intimacy he attempts to establish.

"So long!" appears to occur as it is read. The effect is created, in part, by Whitman's use of the present tense. ${ }^{16}$ Like most of the poems in the 1860 Leaves, "So long!" is written mainly in the present tense. Present-tense verbs of thought, speech, and action equate the moment of making the poem with the moment of reading it: "I adhere to all"; "this moment I set the example" (section 8). Whitman also uses the present participle to create the effect of the poem as an occurrence.

$\mathrm{O}$ thicker and faster!

O crowding too close upon me!

I foresee too much-it means more than I thought,

It appears to me I am dying. (section 15; italics added)

Here, the progressive aspect helps to express death, like life, as a process. In section 17, Whitman includes a catalogue of participles, which, through their implication of duration, express the process of his 
life-screaming, using, glancing, absorbing, alighting, delivering, dropping, unknowing, obeying, never daring, leaving, rising, promulging, bequeathing, explaining, offering, trying. The end of all this is not the "dying" it had appeared to be, but "a melodious echo, passionately bent for-death making me undying."

The paradox of "death making me undying" is developed through the imagery that follows. What had been "a little time vocal, visible" now becomes tactile and at the same time invisible. While invisibility is associated with the death of the poet, tactile imagery is used to describe the coming to life of the text. The text thereby becomes the poet's immortality. Both Number 24 and "So long!" stress the transformation of the book into the human form of the poet. In the earlier poem, at the moment of transmission, the book is transformed into a man: "What you are holding is in reality no book . . . / It is a man, flushed and full-blooded-it is I." "So long!" similarly stresses the personal, physical, tactile attributes of the text. As he brings the book to life, Whitman refers to the physical attributes of both the text and the reader.

This is no book,

Who touches this, touches a man ...

It is I you hold, and who holds you,

I spring from the pages into your arms-(section 20; italics added)

There follows a series of tactile images referring to the reader: "your fingers," "[y]our breath," "your pulse." Thus, the act of reading joins the reader with the text and the writer, so that the writer, too, feels reading as a physical experience: "I feel immerged from head to foot" (section 21). In both Number 24 and "So long!," the final act of transmission is represented by a kiss, a sign of parting representing physically what the poem expresses verbally. The last section of the later "So long!" echoes the words of the earlier one:

Dear friend, whoever you are, here, take this kiss, I give it especially to you . . . (section 23 )

While the reader's engagement with the text is described as a physical experience, the poet himself becomes "no longer visible." "I depart from materials," he declares; "I am as one disembodied, triumphant, dead" (sections 17 and 23). Death and triumph coincide at the poem's end because the text has been brought to life. By denying the textuality of his poetry, by presenting his words not as book but as person, Whitman opposes traditional l'envoi. Most l'envoi poems call attention to the fictive quality of their texts by referring to the book or its pages, lines, or words. Whitman reverses this pattern; with his claim "This is no book," he affirms the life of his poems. 
The life that Whitman assigns to his poetry serves as a bridge between time periods. Both Number 24 and "So long!" stress that in the moment of parting there is also continuity between the past and the future. He suggests it in the meaning of "So long!," the sense of which, as he pointed out to William Sloane Kennedy, is "Till we meet again." He closes the earlier poem with the sentiment, "I hope we shall meet again." In the later poem, he promises continuity with his emphasis on the future: "I announce what comes after me"; "I announce greater offspring, orators, days"; "I am myself the preparer of things farther onward" (sections 1 and 5). The theme is expressed also through the illustration that concludes the 1860 Leaves. A butterfly, wings upward, rests on the index finger of a hand. It is virtually the same illustration that follows the table of contents where the finger points toward the title on page one: "Leaves of Grass, Proto-Leaf." In the final illustration, though, the finger points toward a blank page, as though toward poems yet unwritten.

The image of his poems contributing to the future of poetry is central to Whitman's concept of himself. The sense of passing into the future accounts for the "triumphant" feeling of the persona at the end of "So long!" At the outset of the poem, the hope of influencing poems of the future is expressed conditionally: "All I have done, I would cheerfully give to be trod under foot, if it might only be the soil of superior poems" (section 4). Yet his earlier "Walt Whitman" (eventually, "Song of Myself") affirms that he is to be found in the sod and that poems, like leaves of grass, do in fact rise endlessly out of decaying remains.

I bequeathe myself to the dirt, to grow from the grass I love, If you want me again, look for me under your boot-soles. (section 370)

Alternately hopeful and cautious, Whitman consistently yearns to become a constituent part of future poems, just as poems of the past have become part of him.

The theme of tying the past to the future is central to l'envoi. Chaucer had instructed his "litel bok" to "subgit be to alle poesye" and to "kis the steppes" of preceding poets. Longfellow asked his "voices," "sounds," and "tongues" to speak from beyond the grave. Likewise, Whitman sees his poems as transcending the bounds of the present, drawing nourishment from the past and feeding the future. As Whitman ends Leaves of Grass, he looks both backward and forward. The poem that concludes the book calls to mind its opening counterpart, "ProtoLeaf." The two poems complement each other and frame Leaves of Grass. In the opening poem, as in the closing one, Whitman announces the subjects of his poetry. In "Proto-Leaf," these topics are referred to in the future tense: 
And I will make the poems of my body and of mortality,

For I think $I$ shall then supply myself with the poems of my Soul and of immortality.

(section 19)

In "So long!" the same topics are listed in the present-perfect tense: "I have announced myself on immortality, the body, procreation" (section 8). Both poems refer to announcements, whether future or past, made to readers unknown:

Whoever you are! to you endless announcements.

("Proto-Leaf," section 52)

Dear friend, whoever you are . . . .

("So long!," section 23)

Yet, despite their anonymity, these readers are referred to by Whitman as "friend" ("So long!," section 23) and as "comrade" ("Proto-Leaf," sections 31,32 ) and are invited to journey with him "hand in hand" ("Proto-Leaf," section 65). The union of poet and reader, through the act of reading, is likened to a sexual experience. "O how your fingers drowse me!" murmurs the poet to a reader turning pages. "Your breath falls around me like dew" (section 21). "O adhesiveness," Whitman exclaims in "Proto-Leaf"; and in "So long!" he likewise declares, "I announce adhesiveness."17 What "Proto-Leaf" predicts, "So long!" announces as fulfilled. Perhaps the most compelling fulfillment comes with the cessation of the songs. In "Proto-Leaf" (in lines later incorporated into "Song of Myself"), Whitman writes,

I, now thirty-six years old, in perfect health, begin,

Hoping to cease not till death. (section 11)

"So long!" refers to the poet's "old age" and expresses the thought that death is near: "It appears to me I am dying"; "My songs cease-I abandon them" (sections 15 and 19). "So long!" thus signals closure by fulfilling what "Proto-Leaf" had predicted.

Of course, Whitman never abandoned Leaves for long: a few years after the 1860 Leaves, he produced the first of several later editions. Nonetheless, by framing Leaves of Grass, by defining its beginning and its ending, "Proto-Leaf" and "So long!" form the 1860 text into a fixed object. Concluding thus serves an important function in affirming the monumentality of the work. ${ }^{18}$ What Barbara Herrnstein Smith says regarding closure within a poem can be applied also to the poem as closure: "The devices of closure often achieve their characteristic effect by imparting to a poem's conclusion a certain quality that is experienced by the reader as striking validity, a quality that leaves him with the feeling that what has just been said has the 'conclusiveness,' the settled finality, of apparently self-evident truth." 19 This, in part, is the effect of 
"So long!" It signals not only the end of Leaves but also the permanence and truth of the whole artistic creation.

Ultimately, though, "So long!" fails to leave the reader with a feeling of "settled finality." To be sure, its position at the end of Leaves of Grass suggests closure, as do lines treating the end of the poet's work and life:

To conclude- (section 1)

My songs cease - (section 19)

I feel like one who has done his work- (section 23)

I am as one disembodied, triumphant, dead. (section 23)

At the same time, the poem seems to counteract the idea of closure with words (italicized below) that convey the opposite:

... death making me undying (section 17)

. . with unshut mouth (section 18)

... I advance personally (section 19)

I spring from the pages into your arms-decease calls me forth. (section 20)

... I progress on (section 23)

... awakening rays about me (section 23)

Though the poem serves as closure, the opposite sense of beginning anew is also conveyed. The subversion of closure begins with the paradox of the very first line: "To conclude-I announce what comes after me." With the death of the poet, it would seem, the life of the text begins. When Whitman seems to have stopped, his real work commences, for in "Poets to Come" (1860) he stresses the importance of his future impact on writers. It is "decease," which calls the poet forth into the arms of the reader. The root meaning of "decease" is "to depart"; when the poet "depart[s] from materials," he dies while the text lives. With the death (departure) of the poet, his own poetry comes to life and his impact on future generations of poets begins.

"So long!" emphasizes the connection between literature and life. The type of closure imagined here is extratextual: "When America does what was promised." His poems were written, he says, "with reference to consummations," but these are largely social and political. Whitman seeks completion through the fulfillment of what he announced: 
"greater offspring, orators, days." Yet America, on the brink of war in 1860 , is far from the consummations he envisioned. That curious performative verb, "I announce," offered as if it would bring things into being, underscores Whitman's desperate hope that the assertions of language might become the stuff of life. While the account of his own death is meant to serve as a closural device, it also darkly hints at the dissolution of the country.

This association between language and life accounts for Whitman's odd use of the word translation to signify a passing from one stage into another: "And I announce an old age that shall lightly and joyfully meet its translation" (section 14). Instead of meaning change from one language to another, translation here is used in its alternate sense: "to carry or convey to heaven without death." 20 "Old age" - the poet's, the nation's - is not the end of life but a new beginning. Old poems are destined to become the matter of new poems. New buildings will appear where old ones have decayed: "Clear that rubbish from the buildingspots and the paths!" (section 9). A new "more compact" Union will "make all the previous politics of the earth insignificant" (section 11).

That Whitman associates closure with a sense of going forward is in keeping with his belief in poetry as process. His "Leaves" were not regarded as fixed objects but as organic materials that could grow and change. So the act of closing the text and sending it off to its readers is not the final act of separation of the typical l'envoi poet. Whitman's act is more personal, less definite. Instead of sending his book into the cold unknown, Whitman presents it with a kiss to readers he claims to love. "Is there a single final farewell?" he asks in "So long!" In phrasing the idea as a question, he expresses doubt that such permanent closure is possible. "So long!" is a sign of parting that represents not an ending but a threshold where the past and the future meet.

Texas AEM University

Auburn University

\section{NOTES}

1 For a broad-ranging discussion of literary epilogues, see John S. P. Tatlock, "The Epilog of Chaucer's Troilus," Modern Philology 18 (1921), 113-147.

2 Leaves of Grass, by Walt Whitman: Facsimile of the 1860 Text, intro. Roy Harvey Pearce (Ithaca: Cornell University Press, 1961), 455. Subsequent references will be to this edition.

3 Walt Whitman: Notebooks and Unpublished Prose Manuscripts, ed. Edward Grier (New York: New York University Press, 1984), 4: 1352.

4 See Ovid: Tristia, trans. L. R. Lind (Athens: University of Georgia Press, 1975), 1 and Petrarch's Lyric Poems: The Rime sparse and Other Lyrics, trans. and ed. Robert M. Durling (Cambridge: Harvard University Press, 1976), 262. In French literature, par- 
ticularly in the medieval ballade, l'envoi has less of a connection with exile. French writers turn to l'envoi as a set form, a stanza that provides a conventional closing often addressed to a prince. Eustace Deschamps, Christine de Pizan, Alain Chartier, and Charles D'Orleans were among the many to use the form. See One Hundred Ballades, Rondeaux and Virelais From the Late Middle Ages, ed. Nigel Wilkins (Cambridge: Cambridge University Press, 1969), esp. 70, 76, 78, 82, 84, 90.

5 The Works of Geoffrey Chaucer, ed. F. N. Robinson, 2nd edition (1933; Boston: Houghton Mifflin, 1957), 479.

6 The Works of Edmund Spenser: A Variorum Edition, volume 1, The Minor Poems, ed. Edwin Greenlaw et al. (Baltimore: The Johns Hopkins Press, 1943), 5.

7 The Poetical Works of Robert Southey (Boston: Little, Brown, 1864), 10:371.

8 The Poetical Works of Longfellow (1893; rpt. Boston: Houghton Mifflin, 1975), 11.

9 Leaves of Grass: The First (1855) Edition, ed. Malcolm Cowley (New York: Viking, 1959), 12.

10 The Poetical Works of Longfellow, 349.

11 Leaves of Grass: Comprehensive Reader's Edition, ed. Harold W. Blodgett and Sculley Bradley (New York: New York University Press, 1965), 503n.

12 An illocutionary act, expressing the speaker's intent, is one of three acts, described by John Austin, that a speaker performs in making an utterance. The other two are the locutionary act, referring to the physical act of saying something, and the perlocutionary act, referring to the effect of the utterance upon the audience. It is the illocutionary act, however, that conveys the force of the speaker's utterance (see How to Do Things with Words [Cambridge: Harvard University Press, 1962], 102-103). John Searle has identified five categories of illocutionary acts: 1) representatives (or assertives), such as stating, telling, affirming; 2) directives, such as asking, ordering, commanding, praying; 3) commissives, such as promising, vowing; 4) expressives, such as thanking, congratulating, apologizing; and 5) declarations, such as pronouncing guilt or innocence, appointing, resigning, declaring war. See Searle's "A Classification of Illocutionary Acts," Language in Society 5 (1976), 1-23.

13 See Francois Recanati, Meaning and Force: The Pragmatics of Performative Utterances (Cambridge: Cambridge University Press, 1987), 135.

14 C. Carroll Hollis, Language and Style in Leaves of Grass (Baton Rouge: Louisiana State University Press, 1983), 83, 74. For another useful study of Whitman's style, see James Perrin Warren, Walt Whitman's Language Experiment (University Park: The Pennsylvania State University Press, 1990).

15 Regarding poetic imperatives, see John Hollander, Melodious Guile: Fictive Pattern in Poetic Language (New Haven: Yale University Press, 1988), 79.

16 According to Hollis, $94 \%$ of the poems in the 1860 Leaves are written in the present tense. See Language and Style, 85.

17 For a discussion of Whitman's bond with the reader, see Kerry C. Larson, Whitman's Drama of Consensus (Chicago: University of Chicago Press, 1988), 7-12.

18 See Michael Riffaterre, Semiotics of Poetry (Bloomington: University of Indiana Press, 1978), 21-22. 
19 Barbara Herrnstein Smith, Poetic Closure: A Study of How Poems End (Chicago: University of Chicago Press, 1968), 152.

20 "Translate," The Compact Edition of the Oxford English Dictionary, 1971. 